\title{
Comparative Levels of Immunoglobulin A Urethral Mucosa in Asymptomatic Chlamydia trachomatis Infections in the Prison
}

\author{
Ade Indrayani ${ }^{1}$, , Andi Muhammad Adam ${ }^{1}$, Faridha Ilyas ${ }^{1}$, Safruddin Amin ${ }^{1}$, \\ Burhanuddin Bahar ${ }^{2}$, Rizalinda Sjahrir ${ }^{3}$ \\ ${ }^{1}$ Dermatovenereology Department, Medical Faculty Hasanuddin University, Makassar, Indonesia \\ ${ }^{2}$ Public Health Faculty Hasanuddin University, Makassar, Indonesia \\ ${ }^{3}$ Microbiology Department, Medical Faculty Hasanuddin University, Makassar, Indonesia

\section{Email address:} \\ adhestar@gmail.com (A. Indrayani), Andiadam_exist@yahoo.com (A. M. Adam), Faridha.ilyas@gmail.com (F. Ilyas), \\ ikkkfkuh@yahoo.co.id (B. Bahar), saffruddinamin@yahoo.com (S. Amin), rizalinda_sjahril@yahoo.com (R. Sjahril) \\ ${ }^{*}$ Corresponding author
}

\section{To cite this article:}

Ade Indrayani, Andi Muhammad Adam, Faridha Ilyas, Safruddin Amin, Burhanuddin Bahar, Rizalinda Sjahrir. Comparative Levels of Immunoglobulin A Urethral Mucosa in Asymptomatic Chlamydia trachomatis Infections in the Prison. American Journal of Clinical and Experimental Medicine. Vol. 4, No. 2, 2016, pp. 30-33. doi: 10.11648/j.ajcem.20160402.14

Received: February 8, 2016; Accepted: February 29, 2016; Published: March 28, 2016

\begin{abstract}
Investigation of mucosa immunoglobulin A (IgA) can be used to determine the prevalence of Chlamydia trachomatis (CT) infection, in addition to examination of Polymerase Chain Reaction (PCR) particularly in asymptomatic cases. This research is aimed to compare the levels of IgA mucosal urethral in asymptomatic Chlamydia trachomatis infection and non-infection in male prisoners based on PCR examination in the prison. The methods used was urethral swab specimens collected from 43 asymptomatic male prisoners at the Sidrap Prison in December 2015 and then were examined using PCR method, followed by examination of mucosal IgA levels. The results indicate prevalence of CT based on PCR examination is $2.3 \%$. Based on the examination of PCR, mucosal IgA levels in infected by CT six-fold higher than non-infectious with a mean $\pm \mathrm{SB}(4.45)$ vs $(0.77 \pm 0.52)$ with $\mathrm{p}=0.09$. Based on the examination of mucosal IgA, the level of infected IgA is four-fold higher than non-infectious with a mean $\pm \mathrm{SB}(2.48 \pm 1.41)$ vs $(0.64 \pm 0.21)$, with $\mathrm{p}<0.001$. The combination of a positive PCR results and/or IgA positive with urethral specimen indicate infection of CT, but PCR and IgA in CT infections are not interchangeable but both constitute complementary examination.
\end{abstract}

Keywords: Chlamydia Trachomatis Infection, IgA Mucosal, PCR

\section{Introduction}

Chlamydia trachomatis (CT) is the most common cause of sexually transmitted infections (STIs) caused by Chlamydia spp. which is an obligate intracellular bacterium that require living cells to proliferate. [1] CT infection is known as a silent disease because infected individuals are asymptomatic. If these individuals are not diagnosed and not given treatment, then they become a reservoir of the disease and will lead to longterm complications. [2] There are approximately $50 \%$ of asymtomatic $\mathrm{CT}$ infection of the urethra in men. Asymtomatic of CT infections in men lead to urethritis, proctitis, epididymitis, can even cause infertility. [3]

Immunoglobulin A (IgA) produced by plasma cells found in large numbers in endocervical and urethral penis. In most of the mucosal secretions, IgA concentration more than the $\operatorname{IgG}$ or IgM, especially on endocervical and penile urethra, but in semen and vaginal fluids dominated by $\operatorname{IgG}$. $[4,5]$

Diagnosis based on clinical symptoms and laboratory tests. If there is no clinical symptoms but there are risk factors, should be suspected infection C.trachomatis and laboratory tests should be performed. The criteria for the risk in question is sexual partners more than once in the past month, have sex with female sex workers in the last 1 month, 
experiencing one or more episodes of sexually transmitted diseases in the last 1 year and work wives or sexual partners at high risk. [4]

Chlamydia trachomatis infection in prisoners usually caused by low levels of education and risky sexual activity. The average prevalence of CT infection in males about $6.5 \%$ and women $10 \%$. The population average age is $18-35$ years. Although the average rate of incidence of infection CT small but it is very risky for the wider deployment. [6]

\section{Materials and Methods}

This study was cross sectional design, conducted at Sidrap Prison in Makassar, Indonesian, during December 2015. After receiving approval from the ethics committee on human biomedical research. We obtained 43 subjects asymptomatic male prisoners who appropriate the criteria included in this study. The criteria are male prisoners, aged starting 17-55 years old, a history of sexual intercourse less than 3 months, and willing to participate in the study by signing an informed consent form and fill out the questionnaire.

Samples were collected from urethral swab using a sterile cotton stick and inserted into a container containing $0.5 \mathrm{ml}$ phosphate-buffered saline (PBS). The sample is inserted in the engine coolant at $-20^{\circ} \mathrm{C}$ until the samples is used and then examined using PCR method, followed by mucosal IgA levels.

Data analysis was performed using SPSS version 17. Statistical test was performed using Mann-Whitney and Kruskal-Wallis nonparametric ANOVA with significant value of $\mathrm{p}<0.05$.

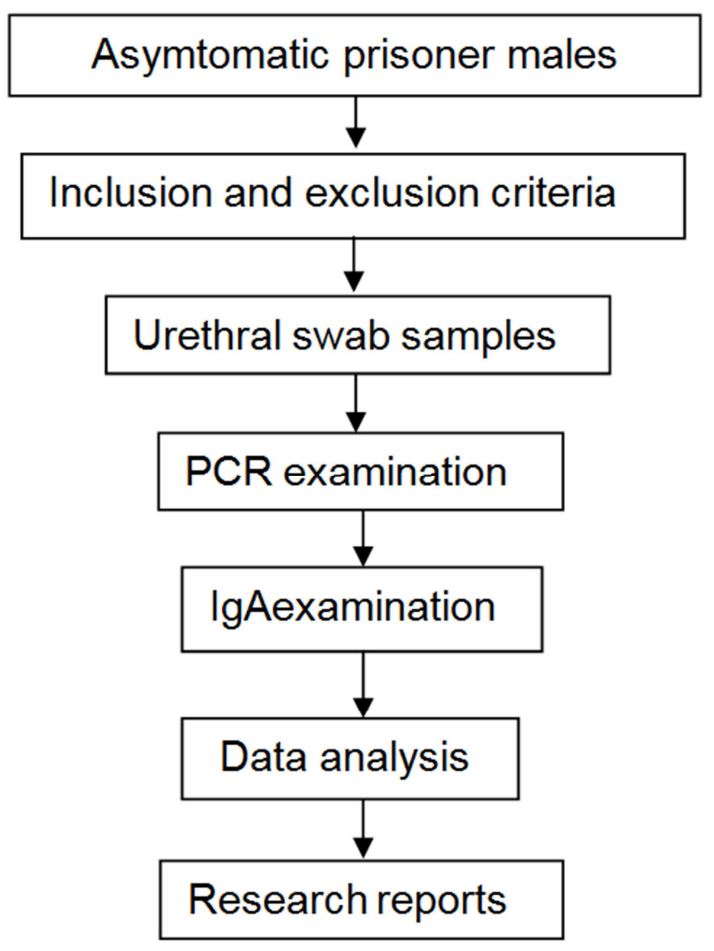

Figure 1. Schematic flow of research.

\section{Result}

Table 1. Characteristics of Sample.

\begin{tabular}{llll}
\hline Characteristics & Category & n & \% \\
\hline Age & $17-28$ & 27 & 62.8 \\
& $29-50$ & 16 & 37.2 \\
PCR & Average \pm SB & $28.49 \pm 8.79$ & \\
& Positive & 1 & 2.3 \\
IgA & Negative & 42 & 97.7 \\
& Positive & 5 & 11.6 \\
& Negative & 38 & 88.4 \\
\hline
\end{tabular}

Description: $\mathrm{PCR}=$ Polymerase Chain Reaction, $\mathrm{Ig} \mathrm{A}=$ Immunoglobulin $\mathrm{A}$, $\mathrm{SB}=$ standard deviations, $\mathrm{n}=$ number, $\%=$ percent.

Table 1 shows that most subjects were in the age group 1728 years, with number 27 samples $(62.8 \%)$, while the lowest of 16 samples in the age group $29-50$ years $(37.2 \%)$. Of the group studied, only one sample $(2.3 \%)$ showed positive PCR results and the five samples (11.6\%) showed positive $\operatorname{IgA}$ results.

Table 2. Comparison of mucosal IgA CT levels by PCR.

\begin{tabular}{lllll}
\hline Variable & & n & Average \pm SB & p-value \\
\hline PCR & Positive & 1 & 4.45 & 0.09 \\
& Negative & 42 & $0.77 \pm 0.52$ & \\
\hline
\end{tabular}

Description: Mann-Whitney Test, PCR = Polymerase Chain Reaction, $\mathrm{n}=$ number, $\mathrm{SB}=$ standard deviations.

Based on Table 2, out of a total of 43 samples showed positive PCR only one sample with average \pm SB 4.45 and negative PCR as many as 42 samples with average \pm SB 0.77 \pm 0.52 with $p=0.09$.

Table 3. Comparison of mucosal IgA CT levels by IgA CT interpretation.

\begin{tabular}{lllll}
\hline \multicolumn{2}{l}{ Variable } & n & Average \pm SB & p-value \\
\hline IgA & Positive & 5 & $2.48 \pm 1.41$ & $<0.001$ \\
& Negative & 38 & $0.64 \pm 0.21$ & \\
\hline
\end{tabular}

Description: Mann-Whitney Test, IgA = Immunoglobulin-A, $\mathrm{n}=$ number, SB $=$ standard deviations.

Based on Table 3, out of a total of 43 samples showed IgA positive in 5 samples with average \pm SB $2.48 \pm 1.41$ and IgA negative as many as 38 samples with average \pm SB $0.64 \pm$ 0.21 , with $p<0.001$ so it can be concluded that there is a significant difference between $\operatorname{IgA}$ positive and IgA negative.

Table 4. Comparison of mucosal IgA CT levels by PCR and IgA CT interpretation.

\begin{tabular}{llllll}
\hline Variable & n & Mean Rank & Mean & SD & p-value \\
\hline PCR (+) IgA (+) & 1 & 43.00 & 4.45 & & \\
PCR (-) IgA (+) & 4 & 40.50 & 2.0 & 0.205 & 0,002 \\
PCR (-) IgA (-) & 38 & 19.50 & 0.64 & & \\
\hline
\end{tabular}

Description: Kruskall-Wallis Test, PCR = Polymerase Chain Reaction, IgA $=$ Immunoglobulin A, $\mathrm{n}=$ number, $\mathrm{SD}=$ standard deviation.

Based on Table 4, out of a total of 43 samples showed positive PCR and IgA positive in one sample with a mean of 4.45 , the negative PCR results and positive IgA obtained by 4 samples with a mean value of 2.0 , while the negative PCR 
results and negative IgA obtained as many as 38 samples with a mean of 0.64 and $p<0.002$.

\section{Discussion}

Characteristics of the sample by age group, showed more on the younger age group as many as 27 samples (62.8\%) (Table 1). In Ontario, Canada, the same thing has been reported that the incidence of $\mathrm{CT}$ found more in young men ages $18-19$ years old (16\%) and 20-24 years (3.7\%). [7] The results to prisoners in Switzerland in 2010 that the prevalence of $6.5 \%$ in men and especially at the age of $18-26$ years. [6] The results of research on prisoners at California in 2006 that the prevalence in men aged less than 25 years as many as 9 , 9\%. [8] Study by Hirst. H to prisoners in Belfast, Northern Ireland in 2009 correspond to this study which is founda $10.5 \%$ prevalence of infected CT mainly young age 17-23 years. [9]

In this study, mucosal IgA levels in infected CT based PCR 6-fold higher than the non-infectious. Statistical analysis was not significant $(p=0.09)$, but there are very high levels between infected CT with non-infectious (Table 2). Mucosal IgA levels in infected CT based inspection of IgA 4-fold higher than the non-infectious and statistically significant $(p<0.001)$ (Table 3). Based on research conducted by. Pate, M. S, et al. found increased levels of IgA significant urethral mucosa is fourfold in the group infected with CT, with $\mathrm{p}<0.0001$. [10]

This study found a positive PCR and IgA positive in 1 sample $(2.3 \%)$, the analysis based on the number of occurrences of pain using study indicator is if the person is regarded as suffering or have suffered from the occurrence of illness proportion of sample 17.69 times higher than the cut off point (COP) -3 SD (0.13). When compared to the cut-off point (COP) - $2 \mathrm{SD}(2.5 \%)$ ratio was 0.92 -fold. This suggests the existence of a disease existing in a population equal to or exceeding expectations of a normal distribution as shown in Table 4. [11, 12]

Local anti-CT antibodies associated with the presence of active infection. The presence of IgA in the vaginal mucosa is a strong indication on the CT infection are ongoing with a low grade in the upper genital tract and when PCR negative at the lower genital tract. The immune response in some infectious diseases involving the production of $\operatorname{Ig} \mathrm{A}$ mucosal or secretory $\operatorname{Ig} \mathrm{A}(\mathrm{s} \operatorname{Ig} \mathrm{A})$, where the predominant immunoglobulin seen in mucosal secretions. The presence of local antibodies in the genital secretions associated with the presence of active infection and will detect exactly sIgA patients still contain microorganisms on their repoduksi tract and can help in the event of termination of therapy. Both local and systemic antibodies can be detected at CT infection. Serology examination is used to diagnose complication of CT infection in upper genital tract and also as a seroepidemiological study tool. The presence of specific antibodies CT significantly associated with infection of the upper genital tract, especially when antibodies showed high titer. [13]
There are 4 samples that showed positive antibody against CT (IgA positive), it indicates that there are 4 samples in this study who were infected by CT or the bacteria have eliminated by antibodies which also means that IgA mucosal is still detected even though the CT germs are absence. These results are consistent with the US Fresse, et al in 2010 reported the prevalence of IgA positive as much as $16.1 \%$ in the high-risk population with a negative PCR. (Table 1). Their result of SIgA in $50 \%$ of patients with positive CT on direct examination and $10.7 \%$ in patients with negative $\mathrm{CT}$ results significantly. The absence of local antibodies in 50\% of patients with CT infection occurred because of different immunological status or associated with upper or lower genital tract infection. [13] Based on the research of Witkin SS. et al, in 1997 found 10 samples with negative PCR results but in IgA examination they found positive results. This occur possibly because of there is an obvious CT infection at that time and the immune response has not disappeared. In addition there is aCT infection in the upper genital tract that trigger the immune response. [14]

\section{Conclusion}

A combination of PCR positive and / or IgA positive urethral specimen is indicative of infection $\mathrm{CT}$ but PCR and IgA in CT infection can not replace each other, but both are complementary examination. Examination of IgA can be used as a screening on $\mathrm{CT}$ infection whereas PCR can be used as a diagnostic.

\section{References}

[1] Eley, A. How to detect Chlamydia trachomatisin males? J of Androl. 2011; 32 (1): 15-22.

[2] Valkengoid, IG, Morre, SA, Brule, AJ, et al. Low diagnostic accuracy of selective screening criteria for asymtomatic Chlamydia trachomatis infection in the general population. Sex Transm Infect. 2000; 76: 375-80.

[3] Louise, MH, Beagley, K., and Timms, P. Chlamydia trachomatis infection: host immune responses and potential vaccine. Mucosal Immunol. 2008; 1 (2): 116-130.

[4] Anderson, DJ Genitourinary immune defense. Holmes, KK, Sparling, PF, Stamm, WE, Piot, P., Wasserheit, JN, Corey, L., Cohen, MS, Watts, DH, editor: Sexually Transmitted Diseases, $4^{\text {th }}$ ed., 2008. New York; McGraw-Hill.

[5] Bernstein, DI and Milligan, GN Mucosal immunity of the Genital Tract. Mestecky, J., Lamm, MF, Strober, W., Bienenstock, J., McGhee, JR, Mayer, L., editor: Mucosal Immunology, $3^{\text {rd }}$ ed. 2005, USA; Elsevier Academic Press.

[6] Steiner, US, Haller, DM, Elger, BS, Seb o, P., Gaspoz, JM, Wolff, H. Chlamydia trachomatis infection in Swiss prison: a cross sectional study. Swiss Med Wkly. 2010; 140: 1-5.

[7] Kouyoumdjian, FG, Main, C., Calzavara, LM, Kiefer, L. Prevalence and predictors of urethral chlamydia and gonorrhea infection in male inmate in an Ontario Corectional Facility. Can J Public Health. 2011; 102 (3): 220-24. 
[8] Bernstein, KT, Chow, JM, Ruiz, J., Schachter, J., Horowitz, E., Bunnell, R., Boian, G. Chlamydia trachomatis and Neisseria gonorrhoeae infection Among men and women entering California Prisons. Am J Public Health. 2006; 96: $1862-1866$

[9] Hirst, H. and Dinsmore, WW Chlamydia Screening Programme, HMP Hydebank Wood Young Offender Centre, Belfast, Northern Ireland, UK. Int J of STD \& AIDS. 2009; 20: $360-1$.

[10] Pate, MS, Hedges, SR, Sibley, DA, Russell, MW, Hook, EW, Mestecky, J. Urethral Cytokines and Immune Responses in Infected Males Chlamydiatrachomatis. Infection and Immunity. 2001; P7178-81.

[11] Esse-Sorlie, D. Medical Biostatistic and Epidemiology. Connecticut: A Simon and chuster Company. 1995; 71-85.
[12] Simpson, J., Berry, G. Normal Distribution. In: Kerr, C et al. Ed's. Handbook of Public Health Methods. Sidney. The Mc Graw Hill Company Inc. 1998; 212-216. 70.

[13] Fresse, USA, Sueur, JM, Hamdad, F. Diagnosis and follow-up of genital chlamydial infection by direct methods and by detection of serum $\operatorname{IgG}, \operatorname{IgA}$, and secretory IgA. IJMM. 2010; 28 (4): 326-31.

[14] Witkin, SS, Bongiovanni, AM, Inglis, SR Detection of Chlamydia trachomatis Endocervical Anti- Immunoglobulin A in Pregnant Women by a Rapid, 6-Minute Enzyme-Linked Immunosorbent Assay: Comparison with PCR and Chlamydial Antigen Detection Methods. J. Clin. Microbiol. 1997; 35: 1781-3. 